\title{
Acclimation of phytoplankton to UV-B radiation: oxidative stress and photoinhibition of photosynthesis are not prevented by UV- absorbing compounds in the dinoflagellate Prorocentrum micans
}

\author{
Michael P. Lesser* \\ Bigelow Laboratory for Ocean Sciences, McKown Point, West Boothbay Harbor, Maine 04575, USA
}

\begin{abstract}
Experiments on the temperate marine dinoflagellate Prorocentrum micans showed that cultures acclimated to moderate intensities $\left(120 \mu \mathrm{mol}\right.$ quanta $\left.\mathrm{m}^{-2} \mathrm{~s}^{-1}\right)$ of visible radiation and supplemental ultraviolet (UV) radiation exhibited significant inhibition of photosynthesis. This inhibition of photosynthesis caused a significant $30 \%$ decrease in specific growth rates for those cells exposed to UV radiation by the end of the $21 \mathrm{~d}$ culture. The mechanism for this decrease in chlorophyll specific photosynthetic rate does not appear to have been damage to photosystem II, as suggested for many acute exposure experiments. Rather, significant decreases in chlorophyll per cell and the specific activities of the carboxylating enzyme, Rubisco, explain the observed decrease in photosynthesis. The decrease in cellular chlorophyll and Rubisco activities occurs despite the presence and accumulation of mycosporine-like amino acids, whose UV absorbing properties have been suggested as an important protective mechanism against the deleterious effects of UV radiation. Our results also implicate oxidative stress, most likely a result of photodynamic interactions, as the cause for the decrease in Rubisco activities. Action spectra generated from these experiments show a significant decrease in the wavelength-dependent effects of UV radiation in cultures exposed to UV radiation, suggesting that UVabsorbing compounds do provide some, if not complete, protection. Previous predictions about specific changes in the shape of action spectra were centered around the absorption maximum of individual UV-absorbing compounds. The observed changes in the overall shape of the UV action spectra for photosynthesis in P. micans can be attributed to the broad overlapping absorption spectra of the suite of UV-absorbing compounds.
\end{abstract}

KEY WORDS: UV-B radiation Oxidative stress Photoinhibition Phytoplankton Photosynthesis

\section{INTRODUCTION}

The decrease of stratospheric ozone from anthropogenic inputs of chlorinated fluorocarbons has resulted in an increase in the amount of harmful ultraviolet (UV) radiation, specifically UV-B, reaching the sea surface (Baker et al. 1980, Solomon 1988). Special attention is focused on the Antarctic, where the auto-

\footnotetext{
- Present address: Department of Zoology and Center for Marine Biology, University of New Hampshire, Durham, New Hampshire 03824. USA.E-mail: mpl@christa.unh edu
}

catalytic destruction of stratospheric ozone ('the ozone hole') leads to enhanced fluxes of UV-B (Frederick \& Snell 1988, Smith \& Baker 1989) and a decrease in primary productivity (Smith et al. 1992, Holm-Hansen et al. 1993, Neale et al. 1994). In tropical waters, UV radiation, both UV-A (320 to $400 \mathrm{~nm})$ and UV-B (290 to $320 \mathrm{~nm}$ ) can penetrate to depths greater than $30 \mathrm{~m}$ (Jerlov 1950, Smith \& Baker 1979, Fleischmann 1989). In southern oceanic waters UV-A can be measured at depths up to $100 \mathrm{~m}$ (Helbling et al. 1994) and UV-B to depths greater than $30 \mathrm{~m}$ (Smith et al. 1992, Helbling et al. 1994). Wavelengths within the UV portion of the 
spectrum are known to have a detrimental effect on photosynthesis and growth in phytoplankton (Lorenzen 1979, Smith \& Baker 1982, Jokiel \& York 1984 Cullen \& Lesser 1991, Cullen et al. 1992, Helbling et al. 1992, Smith et al. 1992, Behrenfield et al. 1994, Lesser et al. 1994, Neale et al. 1994) The molecular targets of UV radiation-induced damage include DNA and proteins, oxidation of membrane lipids, and photooxidation of chlorophyll or damage to photosystem II (Freeman \& Crapo 1982, Asada \& Takahashi 1987, Renger et al. 1989, Neale et al. 1993, Vincent \& Roy 1993).

Ozone depletion is proceeding at a faster rate than anticipated (Rodriguez et al. 1991), and recent studies have indicated a significant decline in stratospheric ozone throughout the northern hemisphere (Blumthaler \& Ambach 1990, Stolarski et al. 1992). These new results suggest that temperate ecosystems may be exposed to higher fluxes of UV radiation, particularly the UV-B portion of the spectrum, than they have been historically. Of particular concern is that ozone depletion results in an increase in damaging UV-B wavelengths without a proportional increase in longer UV-A. and blue wavelengths involved in photoreactivation and photorepair (Smith 1989, Vincent \& Roy 1993). Despite the greater absorption of UV radiation by chlorophyll and dissolved organic matter, generally found in higher concentrations in temperate ecosystems (Smith \& Baker 1979, 1989), the increase in UV-B radiation is likely to have biological effects. Studies on the biological effects of UV-B radiation for these highly productive temperate latitudes are required in order to understand the effects of present day fluxes of UV-B radiation and to make predictions about increases due to ozone depletion. Specifically, and as in the Antarctic, changes in the flux of UV-B radiation are expected to have biological effects on phytoplankton.

One mechanism to ameliorate the effects of solar UV radiation is to block the potentially harmful wavelengths with UV-absorbing compounds. A group of these compounds has an absorption maximum centered around $320 \mathrm{~nm}$. These 'S-320 compounds' were first detected in several reef-building corals and a cyanobacterium by Shibata (1969). Since then a group of compounds, now known as mycosporine-like amino acids (MAAs), have been identified in cyanobacteria (Garcia-Pichel \& Castenholz 1993a) and found in a wide variety of marine organisms, including dinoflagellates (Carreto et al. 1990a, b), macroalgae (Sivalingam et al. 1974, Wood 1989), echinoderms (Nakamura et al. 1981, Shick et al. 1992), numerous corals, zoanthids, sea anemones and other anthozoans (Takano et al. 1978, Hirata et al. 1979, Dunlap \& Chalker 1986, Shick et al. 1991), and a phyletic assortment of Antarctic marine organisms (Karentz et al. $1991 \mathrm{~b})$
A protective role for these compounds has been inferred from their UV-absorbing properties and their logarithmic decrease in concentration with increasing depth in corals (Scelfo 1984, Dunlap et al. 1986). The concentrations of these compounds may also change after shielding from UV exposure or tramsplantation of organisms to shallower depths (Jokiel \& York 1982, Scelfo 1984, Wood 1989, Shick et al. 1991).

The studies by Carreto et al. (1989, 1990a, b) on dinoflagellates appear to be the only published accounts which demonstrate the ability of temperatezone species to change their concentrations of MAAs in response to changing irradiance. Elevated concentrations of MAAs in the red-tide dinoflagellate Alexandrium excavatum were observed when the irradiance was increased from 20 to $200 \mu \mathrm{mol}$ quanta $\mathrm{m}^{-2} \mathrm{~s}^{-1}$, without exposure to UV radiation, suggesting a role for visible radiation in the biosynthesis of MAAs (Carreto et al. 1990a, b). The synthesis of MAAs at high irradiances could be prevented by simultaneous exposure to 3-(3,4-dichlorophenyl)-1,1-dimethylurea (DCMU), an inhibitor of photosynthesis (Carreto et al. 1990a).

Whether these compounds provide full protection from the damaging effects of UV radiation is largely unknown or correlative. Recent evidence for the cyanobacterium Gleocapsa sp., which does produce MAAs after exposure to UV radiation, suggests that MAAs do not provide full protection for the photosynthetic apparatus but augment other cellular acclimatory responses to UV radiation (Garcia-Pichel \& Castenholz 1993a, b). Studies on Antarctic phytoplankton communities have shown that MAAs provide protection. Vernet et al. (1994) found that Antarctic communities dominated by prymnesiophytes with strong absorption in the UV range (320 to $330 \mathrm{~nm}$ ), presumably MAAs, had significantly less UV-induced photoinhibition, while Lesser et al. (unpubl.) observed significantly higher MAA concentrations in McMurdo Sound phytoplankton communities dominated by diatoms exposed to UV radiation. The accumulation of MAAs is one explanation for the lack of any significant differences in the action spectra for UV-induced photoinhibition between cultures of McMurdo Sound phytoplankton communities acclimated with and without UV radiation (Neale et al. 1994)

An alternative approach is to predict the effect of UV-B, and the role of MAAs, based on a quantitative description of the relationship between photosynthetic rate and exposure of phytoplankton to UV radiation. The core of such an approach is the biological weighting function (BWF), or action spectrum (Smith et al. 1980, Rundel 1983, Caldwell et al. 1986, Coohill 1989, Smith 1989). The BWF defines the biologically effective fluence rate (or dose rate) for the biological effect under study, in this case photosynthesis. If the 
presence of UV-absorbing compounds plays a role in the protection of a cell from UV exposure, then the action spectrum for photosynthesis should change its shape in those regions represented by the absorption of MAAs.

The functional aspects of accumulating MAAs for free-living microalgae and cyanobacteria may also depend directly on the optical pathlengths, on the order of microns, of these cells. These small pathlengths can limit the protection of intracellular targets, even with highly absorbing compounds such as MAAs (Garcia-Pichel \& Castenholz 1993a, Garcia-Pichel 1994).

Presented here are experimental results from cultures of the temperate free-living dinoflagellate Prorocentrum micans. These experiments were initiated to assess the long-term effects of chronic exposure to UV$B$ radiation, as many studies utilize acute exposures to UV radiation, and the role of UV-absorbing compounds in the photoacclimation process to UV radiation for this phytoplankter.

\section{MATERIALS AND METHODS}

Culures and experimental conditions. Cultures of the dinoflagellate Prorocentrum micans (Clone PRORO III), obtained from the Provasoli-Guillard Culture Collection for Marine Phytoplankton, were grown on a $12 \mathrm{~h}$ light: $12 \mathrm{~h}$ dark cycle at $20^{\circ} \mathrm{C}$. Two containers (3 1) made of polycarbonate were fitted with a UV transparent (UVT, 50\% cutoff $-285 \mathrm{~nm}$ ) and UV opaque (UVO, $50 \%$ cutoff $-385 \mathrm{~nm}$ ) Plexiglas covering. The cultures were bubbled with acid-scrubbed air, and nutrient-replete semi-continuous cultures were kept in exponential phase using $\mathrm{f} / 2$ growth medium (Guillard 1975). Visible radiation was from Vita-Lite full-spectrum fluorescent lamps providing a quantum scalar irradiance of $120 \mu \mathrm{mol}$ quanta $\mathrm{m}^{-2} \mathrm{~s}^{-1}$ (photosynthetically active radiation, 400 to $700 \mathrm{~nm}$ ) as measured by a Biospherical Instruments QSL $1004 \pi$ sensor immersed in a water-filled culture vessel. These irradiances are known to be saturating for photosynthesis and growth in dinoflagellates with acclimation occurring well within the $21 \mathrm{~d}$ of this experiment (Richardson et al. 1983). Ultraviolet radiation, predominantly UV-B, came from 2 aged $(100 \mathrm{~h})$ fluorescent lamps (FS40 T12-UVB, Light Sources Inc.) covered with cellulose acetate film $10.13 \mathrm{~mm}$ thickness, aged $48 \mathrm{~h}$ at $3 \mathrm{~cm}$ from 4 FS40 lamps). The cellulose acetate was used to attenuate shorter wavelengths that are not encountered in nature (Caldwell et al. 1986) and was changed every $3 \mathrm{~d}$. Both the UV and visible radiation sources were suspended $50 \mathrm{~cm}$ above the cultures. Although these laboratory conditions result in a spec- trally unbalanced light regime, if the cells' lightdependent processes are at irradiance saturation, then a spectral imbalance should have little effect and provide important mechanistic information. The cultures were acclimated under these conditions for $21 \mathrm{~d}$.

Spectral irradiance from the UV lamps was measured using a calibrated diode-array spectroradiometer system (Cullen \& Lesser 1991). Biologically effective irradiances for different treatments were determined as described by Smith \& Baker (1979) and Smith et al. (1980) using the DNA weighting function of Setlow (1974), the generalized plant function of Caldwell (1971), the chloroplast photoinhibition function of Jones \& Kok (1966), and the dinoflagellate photoinhibition weighting function of Cullen et al. (1992).

Biomass, fluorescence, and growth analyses. Chlorophyll, in vivo fluorescence, and particulate $\mathrm{C}$ and $\mathrm{N}$ were analyzed prior to, and after, each experiment. The concentration of chlorophyll a was measured fluorometrically using a calibrated Turner Designs 10005R fluorometer on triplicate samples of $1 \mathrm{ml} \mathrm{col-}$ lected on Whatman GF/F filters and extracted in $10 \mathrm{ml}$ of $90 \%$ acetone and dimethyl sulfoxide (DMSO) $6: 4$ $\mathrm{vol} / \mathrm{vol}$ ) at $-4^{\circ} \mathrm{C}$ in the dark for at least $24 \mathrm{~h}$.

The same fluorometer was used for discrete measurements of the fluorescence of chlorophyll in vivo. Fluorescence was measured after at least 30 min adaptation in the dark and then again after exposure to $3 \times$ $10^{-5} \mathrm{M}$ DCMU in ethanol (Vincent et al. 1980). The initial fluorescence reading $\left(F_{0}\right)$ was made after $15 \mathrm{~s}$ in the fluorometer, then DCMU was added. Fluorescence in the presence of DCMU $\left(F_{\mathrm{m}}\right)$ was recorded after $45 \mathrm{~s}$ in the fluorometer. Distilled water served as the blank. $F_{\mathrm{m}}-F_{0}$ is equivalent to variable fluorescence $\left(F_{\mathrm{v}}\right)$. The cellular fluorescence capacity (CFC) index was then calculated $\left(F_{\mathrm{v}} / F_{\mathrm{m}}\right)$ as a qualitative measure of the relative number of functional PS II units, or the quantum. efficiency of PS II (Vincent et al. 1980).

Triplicate specimens of $50 \mathrm{ml}$ were taken at the beginning of each experiment for determination of particulate carbon and nitrogen. These samples were filtered onto baked $\left(450^{\circ} \mathrm{C}\right.$ for $\left.4 \mathrm{~h}\right) \mathrm{GF} / \mathrm{F}$ filters and stored in a desiccator. Specimens were frozen at $-50^{\circ} \mathrm{C}$ and freeze-dried overnight immediately prior to analysis. Samples were combusted in a Control Equipment Corporation (Perkin Elmer) $240 \mathrm{XA}$ elemental analyzer with an automatic sampler in an air-tight box to keep the samples dry. Acetanilide was used for a standard; pre-filtered culture medium was passed through baked filters and used as blanks. Cell counts were obtained using a Coulter counter model ZM fitted with a $100 \mu \mathrm{m}$ orifice.

Flow cytometery. Chlorophyll per cell, measured as autofluorescence, was measured using a Becton-Dickinson FACS analyzer Single cell measurements were 
made as cells passed through a focused mercury lamp beam at an excitation wavelength of $488 \mathrm{~nm}$. The emitted fluorescent signals were recieved by photomultiplier tubes fitted with $630 \mathrm{~nm}$ long-pass filters. ChIorophyli and cell size (forward angle light scatter, FALS) measurements were made on 5000 cells to yield frequency distribution histograms. The flow cytometer was calibrated with fluorescent beads of known size and checked against cultures of free-living phytoplankton whose cell volume and fluorescent characteristics are known.

Fluorescein diacetate (FDA) was used as a cellular probe to assess the metabolic activity of phytoplankton after the acclimation period. FDA is a lipophilic fluorescent probe that enters the cell and is subsequently cleaved by cellular esterases, resulting in fluorescent fluorescein which can be quantified by flow cytometry. Since these enzymes are involved in phospholipid turnover, the presence of active enzyme is correlated with metabolic activity. The FDA method described by Dorsey et al. (1989) was used to assess the metabolic activity of Prorocentrum micans. FDA is excited using an excitation wavelength of $488 \mathrm{~nm}$, and the emitted yellow-green fluorescent signals were recieved by photomultiplier tubes fitted with a $530 \mathrm{~nm}$ short-pass filter to separate that signal from the red autofluorescence of chlorophyll.

Flow cytometry was also used to assess the level of oxidative stress in the treatment and control cultures (Kobzik et al. 1990). Three specific metabolic probes were utilized: 2',7'-dichlorofluorescein-diacetate [DCF, $25 \mu \mathrm{l}$ of a $1 \mathrm{mM}$ solution (in dimethylformamide) to $250 \mu \mathrm{l}$ of culture and incubate for $5 \mathrm{~min}$ at room temperature] detects intracellular hydrogen peroxide $\left(\mathrm{H}_{2} \mathrm{O}_{2}\right)_{i}$ dihydrorhodamine $123[\mathrm{DHR}, 25 \mu \mathrm{l}$ of a $40 \mu \mathrm{M}$ solution (in dimethylformamide) to $250 \mu \mathrm{l}$ of culture and incubate for $15 \mathrm{~min}$ at room temperature] is a more sensitive indicator of $\mathrm{H}_{2} \mathrm{O}_{2}$ concentrations; and hydroethinide [HE, $25 \mu$ l of a $250 \mu \mathrm{M}$ solution (in dimethylformamide) to $250 \mu$ l of culture and incubate for $15 \mathrm{~min}$ at room temperaturel detects intracellular superoxide radical $\left(\mathrm{O}_{2}^{-}\right)$formation. The excitation wavelength for all 3 probes was $488 \mathrm{~nm}$, and the detection wavelength was 515 to $555 \mathrm{~nm}$ for DCF and DHR, and 600 to $630 \mathrm{~nm}$ for HE. The fluorescent signals of UVO and UVT cultures were collected on the initia] day of the cultures, Days 3, 7,9, 17 and 21 The statistical analysis for all flow cytometry results was done on 1000 cells for each culture on each sampling day using a repeated measures ANOVA.

Antioxidant enzymes. Activities of superoxide dismutase (SOD) and ascorbate peroxidase (ASPX) were assayed spectrophotometrically as described by Lesser \& Shick (1989). Assays were performed on the supernatants of $100 \mathrm{ml}$ of culture material that were filtered onto GF/F filters $(\mathrm{N}=5)$, resuspended in $100 \mathrm{mM}$ phosphate buffer ( $\mathrm{pH} 7.0$ ) and sonicated for 1 min on ice to disrupt the cells. The sonicated suspension was centrifuged for $30 \mathrm{~min}$ at $10000 \mathrm{rpm}$ in a microcentrifuge, and the supernatant retained for the assay of antioxidant enzymes. The protein content of the algal supernatants was measured by the Bradford (1976) method. All enzyme assays were performed in a Shimadzu UV/visible spectrophotometer at $20^{\circ} \mathrm{C}$. Results are expressed as units (U) of enzyme activity per mg protein, where $1 \mathrm{U}=1.0 \mu \mathrm{mol}$ substrate converted $\mathrm{min}^{-1}$.

Carbon uptake. The method of Lewis \& Smith (1983) was used to make measurements of photosynthesis as a function of irradiance $(P-I)$. Samples were inoculated with ${ }^{14} \mathrm{C}$-bicarbonate (final activity, about $10 \mu \mathrm{Ci} \mathrm{ml}^{-1}$ ), and aliquots of $1 \mathrm{ml}$ were dispensed into scintillation vials ( $7 \mathrm{ml}$ capacity) in a temperature-controlled aluminum block. A range of irradiance was provided from below with 2 ENH projection lamps directed through a heat filter of circulating water and attenuated with neutral density screens. Quantum scalar irradiance in each position was measured with a Biospherical Instruments QSL-100 $4 \pi$ sensor with a modified collector. Incubations began within 30 min of sampling and were terminated after 30 min. The $P$-I equation of Platt et al. (1980) was used to model the results where $P_{i}^{B}$ [ $\mu \mathrm{g} \mathrm{C}$ $(\mu \mathrm{g} \mathrm{chl} \mathrm{a})^{-1} \mathrm{~h}^{-1}$ ] is the instantaneous rate of photosynthesis normalized to chl $a$ at irradiance $I$ and $\alpha$, the light-limited rate of carbon uptake, is estimated during the non-linear fitting of the data. The maximum photosynthetic capacity, $P_{\max }\left[\mu \mathrm{g} C(\mu \mathrm{g} \mathrm{chl} \mathrm{a})^{-1} \mathrm{~h}^{-1}\right]$, was calculated according to Platt et al. (1980).

Activities of 1,5 ribulose bisphosphate carboxylase/ oxygenase (Rubisco) were measured using the method of Glover \& Morris (1979), which follows the uptake of ${ }^{14} \mathrm{C}$-bicarbonate $\left(0.25 \mu \mathrm{Ci} \mu \mathrm{mol}^{-1}\right)$ at $20^{\circ} \mathrm{C}$ using the optimal substrate conditions for the enzyme, and were expressed on a chlorophyll basis to allow comparison of these activities directly to the P-I curves.

Mycosporine-like amino acids (UV-absorbing compounds). At the end of the experimental period $100 \mathrm{ml}$ aliquots ( $N=3$ ) were filtered as described above and placed in $3 \mathrm{ml}$ of $100 \%$ methanol. Extraction, separation, and quantification of MAAs were performed using reverse-phase high performance liquid chromatography (HPLC), as originally described by Dunlap \& Chalker (1986) and modified by Karentz et al. (1991b) and Shick et al. (1992). Individual MAAs were separated by reverse-phase isocratic HPLC on a Brownlee RP-8 column protected with an RP-8 guard, in an aqueous mobile phase including $0.1 \%$ acetic acid and 25 or $55 \%$ methanol. Detection of peaks was by UV absorbance at 313 and $340 \mathrm{~nm}$. Identities of peaks were confirmed by co-chromatography using known standards in an aqueous mobile phase of $0.1 \%$ acetic 
Table 1 Biologically weighted UV irradiance $\left(\mathrm{mW} \mathrm{m}^{-2}\right.$ 290-400 nm) and unweighted UV-B irradiance ( $\mathrm{mW} \mathrm{m}^{2}$, 290-320 nm) for the cellulose acetate filtered FS40 lamps used for the experiments on Prorocentrum micans. The weightings tabulated by Smith et al. (1980) were used unless otherwise noted

\begin{tabular}{|c|c|c|}
\hline Weighting function & Treatment & $\begin{array}{l}\text { UV irradiance } \\
\left(\mathrm{mW} \mathrm{m}^{-2}\right)\end{array}$ \\
\hline DNA & $\begin{array}{l}\text { UVO } \\
\text { UVT }\end{array}$ & $\begin{array}{l}0.00 \\
0.61\end{array}$ \\
\hline Plant & $\begin{array}{l}\text { UVO } \\
\text { UVT }\end{array}$ & $\begin{array}{l}0.00 \\
5.38\end{array}$ \\
\hline Photoinhibition & $\begin{array}{l}\text { UVO } \\
\text { UVT }\end{array}$ & $\begin{array}{r}1.52 \\
72.37\end{array}$ \\
\hline Photoinhibition" & $\begin{array}{l}\text { UVO } \\
\text { UVT }\end{array}$ & $\begin{array}{r}0.28 \\
13.41\end{array}$ \\
\hline Unweighted UV-B $(290-320 \mathrm{~nm})$ & $\begin{array}{l}\text { 1) UVO } \\
\text { UVT }\end{array}$ & $\begin{array}{r}0.00 \\
88.44\end{array}$ \\
\hline Unweighted UV $(290-400 \mathrm{~nm})$ & $\begin{array}{l}\text { UVO } \\
\text { UVT }\end{array}$ & $\begin{array}{r}17.98 \\
255.24\end{array}$ \\
\hline
\end{tabular}

acid and 55\% methanol. MAA concentrations were calculated using standards for mycosporine-glycine, shinorine, porphyra-334, palythine, asterina-330, and palythinol, and were normalized to soluble protein.

Action spectra. A newly constructed analytical model of photosynthetic response to irradiance was used to describe the interaction of UV and photosynthetically active radiation (PAR, ca 400 to $700 \mathrm{~nm}$ ) on photosynthesis. In this biological weighting function/ $P$-I model, photoinhibition is dependent on both absolute UV irradiance and UV relative to PAR (Cullen et al. 1992). The long-pass filter cut-off wavelengths were chosen to define irradiance treatments containing progressively greater amounts of first UV-A and then UV-B, added to a constant background of PAR. This 'polychromatic' approach was chosen to obtain environmentally relevant action spectra (Caldwell et al. 1986). The weightings obtained using these procedures are absolute rather than relative and can be compared directly without normalizing the action spectrum to some nominal wavelength at which the greatest wavelength-dependent effects are observed. A detailed description of the model and analytical approach is given in Cullen et al. (1992) and Neale et al. (1994)

\section{RESULTS}

\section{Biologically effective irradiances of UV radiation}

Semi-continuous cultures of Prorocentrum micans grown at saturating PAR irradiances were exposed to an unweighted UV-B irradiance (Table 1, $88.44 \mathrm{~mW}$ $\mathrm{m}^{-2}$ ) that was considerably less than the irradiance observed at the surface $\left(1 \mathrm{~m}, 1.26 \times 10^{3} \mathrm{~mW} \mathrm{~m}^{-2}\right)$ during June in the Gulf of Maine, USA (Lesser unpubl.). In spite of the spectral imbalance of the laboratory photic regime this represents only $7 \%$ of the ambient UV-B dose for typical mid-latitude waters at the surface. Biologically effective irradiances of UV-B radiation were calculated using several different weighting functions (Table 1). The photoinhibition weighting functions show an almost 50-fold difference in biologically effective UV-B dose between experimental and control cultures (Table 1).

\section{Growth rates}

Significant effects of UV radiation on specific growth rates, $\mathrm{C}: \mathrm{N}$ ratios, chlorophyll per cell, and cell concentrations were observed. UVT cultures had significantly lower rates of chlorophyll-specific growth, decreased chlorophyll per cell, and a decrease in cell concentrations after the 21 d acclimation period (Table 2). Cell-specific growth rates were not significantly different from one another (Table 2). The C:N ratios for UVT cultures were significantly higher, while no differences were observed for the CFC ratio (Table 2)

Table 2. Effects of UV radiation on growth, biomass, and biochemistry for UVO and UVT cultures of Prorocentrum micans (mean \pm SD). Probability (p) values are from an ANCOVA analysis of slopes for the growth rates and from an unparred Student's $t$-test at the $5 \%$ significance level for the remaining analyses

\begin{tabular}{|lccc|}
\hline Parameter & Treatment & Result & $p$ \\
\hline Growth (chlorophyll specific, $\mathrm{d}^{-1}$ ) & UVO & $0.111 \pm 0.0093$ & 0.044 \\
& UVT & $0.076 \pm 0.0109$ & \\
Growth (cell specific, $\mathrm{d}^{-1}$ ) & UVO & $0.265 \pm 0.064$ & $>0.05$ \\
& UVT & $0.215 \pm 0.061$ & \\
Cell numbers $\left(\times 10^{3} \mathrm{ml}^{-1}\right.$ ) & UVO & $8.21 \pm 0.49$ & 0.002 \\
& UVT & $5.67 \pm 0.52$ & \\
Chlorophyll a cell-1 & UVO & $13.93 \pm 1.03$ & 0.004 \\
& UVT & $8.26 \pm 1.26$ & \\
C: N ratio & UVO & $5.33 \pm 0.11$ & 0.027 \\
CFC ratio & UVT & $5.69 \pm 0.33$ & \\
& UVO & $0.61 \pm 0.022$ & 0.41 \\
& UVT & $0.59 \pm 0.018$ & \\
& & & \\
& & &
\end{tabular}


Table 3. Effects of UV radiation on metabolic activity and oxidative stress for UVO and UVT cultures of Prorocentrum micans (mean \pm SD). Probability (p) values are from a repeated measures ANOVA (flow cytometry data) or an unpaired Student's $t$-test (antioxidant enzyme activities) at the $5 \%$ significance level

\begin{tabular}{|c|c|c|c|}
\hline Flow cytometry & Treatment & Result & $\mathrm{p}$ \\
\hline FDA fluorescence cell ${ }^{-1}$ & $\begin{array}{l}\text { UVO } \\
\text { UVT }\end{array}$ & $\begin{array}{l}38 \pm 15 \\
36 \pm 15\end{array}$ & $>0.05$ \\
\hline $\mathrm{HE}\left(\mathrm{H}_{2} \mathrm{O}_{2}\right)$ fluorescence cell ${ }^{-1}$ & $\begin{array}{l}\text { UVO } \\
\text { UVT }\end{array}$ & $\begin{array}{l}267 \pm 106 \\
295 \pm 114\end{array}$ & 0.0001 \\
\hline DHR $\left(\mathrm{H}_{2} \mathrm{O}_{2}\right)$ fluorescence cell ${ }^{-1}$ & $\begin{array}{l}\text { UVO } \\
\text { UVT }\end{array}$ & $\begin{array}{l}290 \pm 89 \\
299 \pm 83\end{array}$ & 0.005 \\
\hline $\mathrm{DCF}\left(\mathrm{O}_{2}-\right)$ fluorescence cell ${ }^{-1}$ & $\begin{array}{l}\text { UVO } \\
\text { UVT }\end{array}$ & $\begin{array}{l}333 \pm 155 \\
347 \pm 175\end{array}$ & 0.02 \\
\hline SOD activity ( $\mathrm{U} \mathrm{mg}^{-1}$ protein) & $\begin{array}{l}\text { UVO } \\
\text { UVT }\end{array}$ & $\begin{array}{l}2.73 \pm 2.60 \\
6.42 \pm 1.09\end{array}$ & 0.009 \\
\hline ASPX activity ( $\mathrm{U} \mathrm{mg}^{-1}$ protein) & $\begin{array}{l}\text { LVO } \\
\text { LVT }\end{array}$ & $\begin{array}{r}2.63 \pm 0.65 \\
11.45 \pm 3.40\end{array}$ & 0.0002 \\
\hline
\end{tabular}

\section{Flow cytometry}

All measurements of the cellular concentration of hydrogen peroxide and superoxide radicals showed a significant treatment effect, with UVT cultures always having higher concentrations of these reduced oxygen

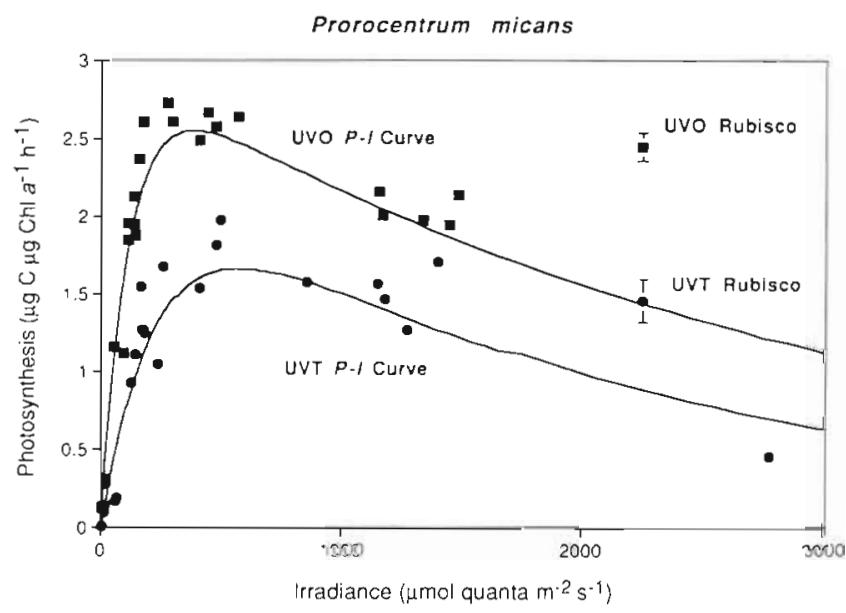

Fig. 1. Photosynthesis-irradiance $(P-I)$ curves from UVO (opaque to UV radiation) and UVT (transparent to UV radiation) from Day 21 of the long-term cultures. Values for $P_{\max }$ $[U V O=2.66 \pm 0.09(\mathrm{SE}), \mathrm{UVT}=1.63 \pm 0.076(\mathrm{SE})]$, and $\alpha[\mathrm{UVO}$ $=0.025(\mathrm{SE}) \pm 0.003, \mathrm{UVT}=0.010 \pm 0.004$ (SE)] were significantly different from one another ( $t$-test, $p<0.05$ ). Chlorophyllspecific values for Rubisco $(\mathrm{N}=3$; UVO $=2.45 \pm 0.09$ (SD), $\mathrm{UVT}=1.46 \pm 0.14$ (SD)] were also significantly different from each other [ANOVA, $p<0.05$; Student-Newman-Keuls (SNK) multiple comparison test ${ }_{i} \mathrm{p}<0.051$ while the UVO treatment was not significantly different from pre-UV radiation exposure activities $\mid 2.55 \pm 0.07$ (SD) $\mid$ of the culture (ANOVA, $p<$ $0.05 ;$ SNK, $p<0.05$ ) products (Table 3). Additionally, both chlorophyll (measured as autofluorescence) and cell size (measured as FALS) showed a significant effect of exposure to UV radiation. Chlorophyll content per cell decreased, supporting the bulk chlorophyll analysis, and cell size increased significantly in cells exposed to UV radiation. For all cases, the repeated measures ANOVA detected a significant independent and interactive effect of time $(p<0.05)$ which showed an increase in the effects of UV radiation on chlorophyll, cell size, and cellular concentration of active species of oxygen with time or exposure. There was no significant ( $p<$ $0.05)$ difference in FDA-staining characteristics, indicating that there was no difference in metabolic rates measured by this assay.

\section{Antioxidant enzymes}

Supporting the direct measurement of active species of oxygen by flow cytometry are the specific activities of the antioxidant enzymes, superoxide dismutase and ascorbate peroxidase. Significant differences in the specific activites of these enzymes were observed with UVT cultures expressing higher activities (Table 3).

\section{Photosynthesis-irradiance curves}

After $21 \mathrm{~d}$ of acclimation the UVT culture showed a significant depression of maximum photosynthetic capacity $\left(P_{\max }\right)$ and light-limited rate of carbon uptake $(\alpha)$ (Fig. 1). Additionally, a significant decrease in the chlorophyll-specific activities of Rubisco was detected (Fig. 1), which corresponds with the observed changes in the maximum photosynthetic capacity of these cultures (Fig. 1)

\section{Mycosporine-like amino acids}

Quantitative chromatography showed the presence of 4 different MAA compounds. Significantly $(p<0.05)$ higher concentrations of mycosporine-glycine, shinorine, and porphyra-334 were noted in UVT cultures (Fig. 2), while asterina-330 was significantly higher in UVO cultures. Total MAA concentration was signifi-

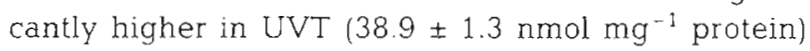

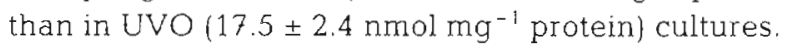




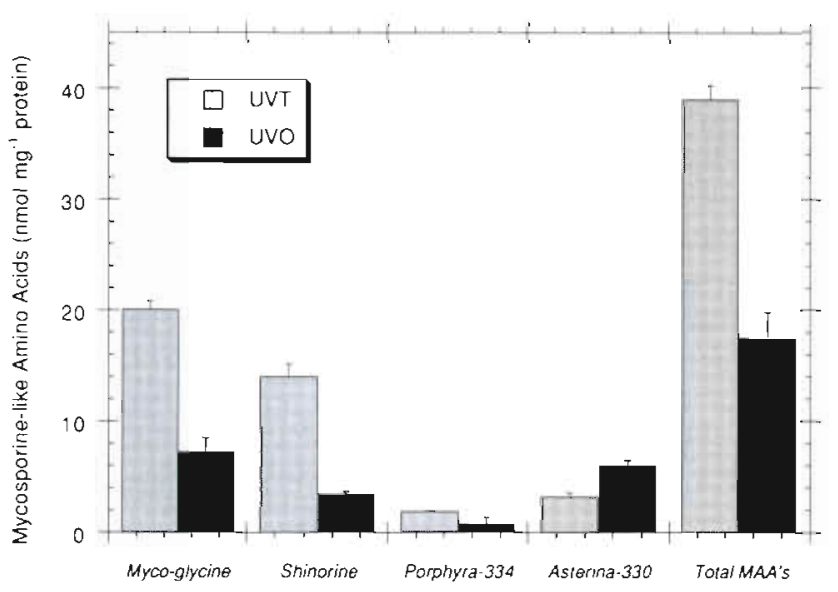

Fig. 2. Concentrations of mycosporine-like amino acids (MAAs; mean \pm SD) from UVT and UVO cultures of Prorocentrum micans normalized to soluble protein. Differences in the concentrations of MAAs were assessed using an unpaired Student's $t$-test at the 0.05 level of probability. Significant (N $=3 ; p<0.05$ ) differences of all individual MAAs and total MAA concentrations were observed

\section{Action spectra}

The biological weighting functions (action spectra) for UVT and UVO cultures exhibit similar shapes, and there is some suggestion of a specific shape change in the UVT treatment between 330 and $350 \mathrm{~nm}$, an area of high absorbance for MAAs (Fig. 3). However, the absolute magnitudes of these biological weighting functions are significantly (no overlap in their 95\% confidence intervals of the estimates) different in their wavelength-dependent UV radiation effects on photosynthesis between 285 and $345 \mathrm{~nm}$, allowing only subjective comments on differences in the shape, and the

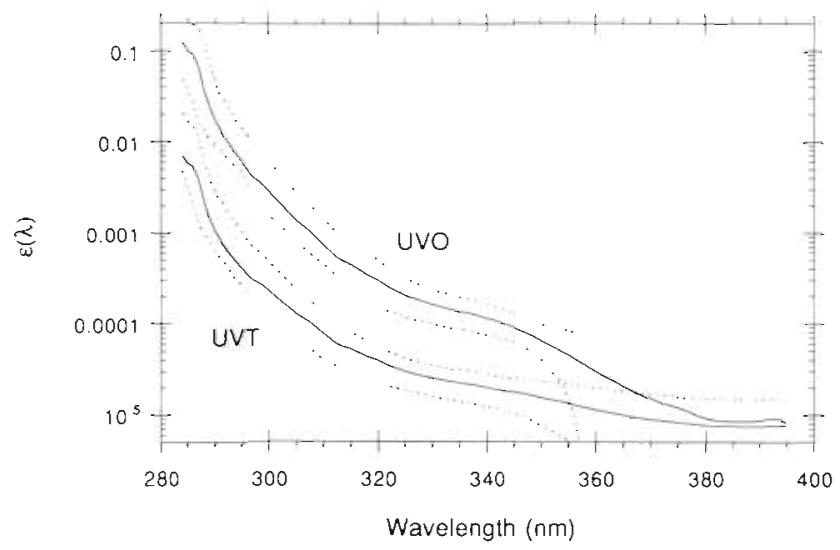

Fig. 3. Polychromatic action spectra (biological weighting function) for UVT and UVO cultures; $\varepsilon(\lambda)=\left(\mathrm{mW} \mathrm{m}^{-2}\right)^{-1}$ Significant differences (no overlap between $95 \%$ confidence intervals (dotted lines)] betiween the 2 action spectra are observed between 285 and $345 \mathrm{~nm}$ cause of any changes in shape, in the area between 285 and $345 \mathrm{~nm}$

\section{DISCUSSION}

After $21 \mathrm{~d}$ of acclimation, cultures exposed to UV radiation show a significant depression of maximum photosynthetic capacity and light-limited photosynthetic rates. The mechanism for this decrease in chlorophyll-specific photosynthetic rate does not appear to be damage to photosystem II (PS II), as suggested by measurements of the quantum yield of fluorescence for PS II (Table 2; CFC), although oxidative stress has been shown to cause damage to PS II at the D1 protein (Richter et al. 1990). There was, however, a transient decrease in the quantum yield of fluorescence in cultures exposed to UV-B radiation initially (data not shown). These values increased over the time course of the experiments and the quantum yield of fluorescence values were not significantly different between the 2 cultures at the end of the experiment, suggesting that the number of functional PS II units was equivalent at that time. Rather than damage to PS II, a significant decrease in the specific activities of the carboxylating enzyme Rubisco, and chlorophyll content per cell, explains the observed decrease in photosynthesis. Decreases in cellular chlorophyll content have been observed in previous experiments on the effects of UV radiation, but these decreases did not explain the lower rates of photosynthesis (Lesser et al. 1994). Rubisco, however, is known to be sensitive to the direct and indirect effects of UV-B radiation in terrestrial plants and phytoplankton (Vu et al. 1984, Strid et al. 1990, Neale et al. 1993), and decreases in the specific activities of Rubisco are known to principally affect maximum photosynthetic capacity (Glover 1989). Alternatively, undetectable damage to PS II, using the techniques in this study, could result in the down regulation of other components of the photosynthetic apparatus, including Rubisco (Strid et al. 1990).

The indirect effects of UV-B radiation on Rubisco are mediated by active species of oxygen. In particular, Rubisco is sensitive to hydrogen peroxide $\left(\mathrm{H}_{2} \mathrm{O}_{2}\right)$, which occurs in high concentration in illuminated chloroplasts (Asada \& Takahashi 1987). The presence of higher specific activities of superoxide dismutase and ascorbate peroxidase in Prorocentrum micans exposed to UV-B radiation suggests that a higher flux of active oxygen species is occurring in these cells. Direct analysis of superoxide radicals and hydrogen peroxide in individual cells by flow cytometry shows a significantly higher concentration of these toxic oxygen species in cells exposed to UV-B radiation, which is likely to have been generated via photodynamic 
action with various cellular constituents (Valenzeno \& Pooler 1987). Although statistically different and potentially related to UV-B effects on nitrate uptake (Döhler 1986), the differences in C: $\mathrm{N}$ ratios are less than $6 \%$ and probably had little effect on cellular performance. The decrease in photosynthetic rates and the investment in protective enzymes and UV-absorbing compounds (see below) manifests itself as a significant $34 \%$ decrease in chlorophyll-specific growth rate, and, consequently, cell numbers by the end of the experimental period. The cell-specific growth rate, although $19 \%$ lower for cells exposed to UV radiation, was not statistically different from control cultures. These results do not preclude the possibility that damage to DNA, induced by the direct and indirect effects of UV-B radiation, partially or fully caused the observed decreases in growth rate (Karentz et al. 1991a)

The decrease in photosynthetic performance, chlorophyll content, and Rubisco activities occurs despite the presence and accumulation of MAAs in those cultures exposed to UV-B radiation. High concentrations of UVabsorbing compounds have been shown to cause high in vivo absorbances within the UV portion of the spectrum that does not function in photosynthetic light harvesting for Prorocentrum micans (Vernet et al. 1989). The total concentration of MAAs in cultures exposed to $U V-B$ radiation is almost twice the concentration in dinoflagellates not exposed to UV-B radiation, with the greatest differences in mycosporine-glycine $\left(\lambda_{\max }=\right.$ $310 \mathrm{~nm})$ and shinorine $\left(\lambda_{\max }=334 \mathrm{~nm}\right)$. Using the sunscreen factor $(S)$ for Gonyaulax polyedra $(S=0.59$; Table 2 therein) from Garcia-Pichel (1994) as the most appropriate based on the size range of $P$. micans (22 to $38 \mu \mathrm{m})$, it then follows that the dose of UV radiation required to inhibit photosynthesis in $P$. micans containing MAAs should have been approximately 2.43 times that needed had there been no sunscreens (GarciaPichel 1994) The biologically effective dose, using the photoinhibition function of Cullen et al. (1992), of UV radiation for UV-acclimated cultures was almost 50 times that experienced by control cultures. It also follows that, since cells exposed to UV radiation were substantially less inhibited than might be expected from these irradiances, mechanisms are being employed to counteract the damaging effects of UV radiation. Cells of $P$. micans are, therefore, provided protection by the accumulation of MAAs, but not without damage to Rubisco or other cellular targets (e.g. DNA) that might result from oxidative stress which subsequently results in a depression of photosynthetic capacity and growth.

Action spectra generated from these experimental cultures show a substantial decrease in UV effects, both UV-A between 320 and $345 \mathrm{~nm}$ and all of the UV-
B portion of the spectrum, for cultures exposed to UV$B$ radiation. Again, differences in the wavelengthdependent effects of UV radiation between the 2 cultures are significant between 285 and $345 \mathrm{~nm}$, supporting a role for UV-absorbing compounds in decreasing the effect of UV radiation on photosynthetic capacity in acclimated cultures. As shown by Lesser et al. (1994\}, part of the response of phytoplankton to UV radiation is a new equilibrium between damage and repair processes. Therefore, the responses observed in cultures acclimated with UV radiation is a result of this new equilibrium and may not reflect any additional UV radiation stress during the action spectrum measurement, while the control cultures represent an acute exposure. The total doses and dosage rates applied during the action spectrum measurement, however, are higher than the acclimation regime and may result in additional inhibition of photosynthesis even though the action spectrum for UV-acclimated cultures showed a decrease in the wavelength-dependent effects compared to cultures not acclimated with UV radiation. Previous predictions about specific changes in the shape of action spectra were centered around the absorption maximum of individual UVabsorbing compounds. The overall change in the magnitude of the wavelength-dependent effects for the action spectra, rather than a shape change in a specific region, for photosynthesis of Prorocentrum micans can be attributed, in part, to the broad overlapping absorption spectra of the suite of MAAs found in P. micans and other repair processess or bio-optical properties of these cells.

The data presented here provide strong evidence that MAAs do not provide complete protection for this dinoflagellate, and possibly phytoplankton in general, but are part of an overall response to the direct and indirect effects of UV radiation. The functional aspects of accumulating MAAs for free-living microalgae and cyanobacteria may also depend directly on the optical pathlengths, on the order of microns, for these cells since an increase in cell diameter (pathlength) increases the probability that a photon of UV radiation will interact with a homogeneously distributed UVabsorbing compound (Garcia-Pichel \& Castenholz 1993a, b. Garcia-Pichel 1994). Karentz et al. (1991a) showed a negative relationship between the formation of DNA photoproducts, indicating damage to DNA, and cell size. Smaller cells with an increase in the surface area to volume relationship showed more damage per unit DNA. Mean cell size differences in Prorocentrum micans are most likely the result of slower growth rates (Gallagher \& Alberte 1985) for cultures exposed to UV radiation. The changes in the optical pathlengths in these cells and higher MAA concentration also contribute to preventing further damage. For 
larger species of phytoplankton or colony formers, the optical pathlengths will be much longer and presumably result in an increase in the absorbance of UV radiation by these compounds. The optical pathlength of phytoplankton, being dependent upon cell size, will also be affected by photoacclimatory state, nutrient status, and ultrastructural organization (Dubinsky 1992). These varying pathlengths can potentially limit the protection of intracellular targets from UV radiation as shown by Garcia-Pichel (1994), even with the accumulation of UV-absorbing compounds such as MAAs.

Acknowledgements. This work was supported by the National Science Foundation Office of Polar Programs (DPP9018441) and Biological Oceanography (OCE-9216307/OCE9496082). A special thank you to Terry Cucci, Michael Sieracki, and Clarice Yentsch from the Flow Cytometry facility at Bigelow Laboratory for Ocean Sciences for their advice and assistance. I also thank $J$. Cullen for his support and advice and $P$. Neale for computational assistance on the action spectra. Standards for UV-absorbing compounds were synthesized by Walter Dunlap (the Australian Institute of Marine Science) and provided by Deneb Karentz (University of San Francisco). This is Bigelow Laboratory for Ocean Sciences contribution number 95008

\section{LITERATURE CITED}

Asada K, Takahashi M (1987) Production and scavenging of active oxygen in photosynthesis. In: Kyle DJ, Osmond CB, Arntzen CJ (eds) Photoinhibition. Elsevier, Amsterdam, p 228-287

Baker KS, Smith RC, Green AES (1980) Middle ultraviolet radiation reaching the ocean surface. Photochem Photobiol 32:367-374

Behrenfield MJ, Lee IIH, Small LF (1994) Interactions between nutritional status and long-term responses to ultraviolet-B radiation stress in a marine diatom. Mar Biol 118:523-530

Blumthaler M, Ambach W (1990) Indication of increasing solar ultraviolet- $B$ radiation flux in alpine regions. Science 248:206-208

Bradford MM (1976) A rapid and sensitive method for the quantification of microgram quantities of protein utilizing the principle of protein-dye binding. Analyt Biochem 72: $248-254$

Caldwell MM (1971) Solar ultraviolet radiation and the growth and development of higher plants. In: Giese AC (ed) Photophysiology. Academic, New York, p 131-177

Caldwell MM, Camp LB, Warner CW, Flint SD (1986) Action spectra and their key role in assessing biological consequences of solar UV-B radiation change. In: Worrest $\mathrm{RC}$, Caldwell MM (eds) Stratospheric ozone reduction, solar ultraviolet radiation and plant life. Springer-Verlag. New York, p 87-111

Carreto JI, Carignan MO, Daleo G, De Marco SG (1990a) Occurrence of mycosporine-like amino acids in the redtide dinoflagellate Alexandrium excavatum: UV-photoprotective compounds? J Plankton Res 12:909-921

Carreto JI, De Marco SG, Lutz VA (1989) UV-absorbing pigments in the dinoflagellates Alexandrium excavatum and
Prorocentrum micans. Effects of light intensity. In: Okaichi $\mathrm{T}$, Anderson DM, Nemoto $\mathrm{T}$ (eds) Red tides, biology, environmental science and toxicology. Elsevier, New York, p 333-336

Carreto JI, Lutz VA, De Marco SG, Carignan MO (1990b) Fluence and wavelength dependence of mycosporine-like amino acid synthesis in the dinoflagellate Alexandrium excavatum. In: Granéli E, Edler $L$, Sundström B, Anderson DM (eds) Toxic marine phytoplankton. Elsevier, New York, p 275-279

Coohill TP (1989) Ultraviolet action spectra (280 to $380 \mathrm{~nm}$ ) and solar effectiveness spectra for higher plants. Photochem Photobiol 50:451-457

Cullen JJ, Lesser MP (1991) Inhibition of phytoplankton photosynthesis by ultraviolet radiation as a function of dose and dosage rate. Mar Biol 111:183-190

Cullen JJ, Neale PJ, Lesser MP (1992) Biological weighting function for the inhibition of phytoplankton photosynthe. sis by ultraviolet radiation. Science 258:646-651

Döhler G (1986) Impact of UV-B radiation on $\left[{ }^{15} \mathrm{~N}\right]$ ammonia and $\left[{ }^{15} \mathrm{~N}\right]$ nitrate uptake of Dictylum brightwellii. Photochem Photobiophys 11:115-121

Dorsey J, Yentsch CM, Mayo S, McKenna C (1989) Rapid analytical technique for the assessment of cell metabolic activity in marine microalgae. Cytometry 10:622-628

Dubinsky Z (1992) The functional and optical absorption cross-sections of phytoplankton photosynthesis. In: Falkowski PG, Woodhead AD (eds) Primary productivity and biogeochemical cycles in the sea. Plenum Press, New York, p 31-45

Dunlap WC, Chalker BE (1986) Identification and quantitation of near-UV absorbing compounds (S-320) in a hermatypic scleractinian. Coral Reefs 5:153-159

Dunlap WC, Chalker BE, Oliver JK (1986) Bathymetric adaptations of reef-building corals at Davies Reef, Great Barrier Reef, Australia. III. UV-B absorbing compounds. J exp mar Biol Ecol 104:239-248

Fleischmann EM (1989) The measurement and penetration of ultraviolet radiation into tropical marine water. Limnol Oceanogr 34:1623-1629

Frederick JE, Snell HE (1988) Ultraviolet radiation levels during the Antarctic spring. Science 241:438-440

Freeman BA, Crapo JD (1982) Biology of disease: free radicals and tissue injury. Lab Invest 47:412-426

Gallagher JC, Alberte RM (1985) Photosynthetic and cellular photoadaptive characteristics of three ecotypes of the marine diatom, Skeletonema costatum (Grev.). J exp mar Biol Ecol 94:233-250

Garcia-Pichel F (1994) A model for internal self-shading in planktonic organisms and its implications for the usefulness of ultraviolet sunscreens. Limnol Oceanogr 39: $1704-1717$

Garcia-Pichel F, Castenholz W (1993a) Occurrence of UVabsorbing, mycosporine-like compounds among cyanobacterial isolates and an estimate of their screening capacity. Appl environ Microbiol 59:163-169

Garcia-Pichel F, Castenholz W (1993b) Evidence regarding the UV-sunscreen role of a mycosporine-like compound in the cyanobacterium Gleocapsa sp. Appl environ Microbiol 59:170-176

Glover HE (1989) Ribulose carboxylase/oxygenase in marine organisms. Int Rev Cytol 115:67-138

Glover HE, Morris I (1979) Photosynthetic carboxylating enzymes in marine phytoplankton. Limnol Oceanogr 24 : $510-519$

Guillard RRL (1975) Culture of phytoplankton for feeding marine invertebrates. In: Smith WL, Chanley $\mathrm{MH}$ (eds) 
Culture of marine invertebrate animals. Plenum Press, New York, p 29-60

Helbling EW, Villafane V, Ferrario M, Holm-Hansen O (1992) Impact of natural ultraviolet radiation on rates of photosynthesis and on specific marine phytoplankton specins. Mar Ecol Prog Ser 80:89-100

Helbling EW, Villafane V. HoIm-Hansen O (1994) Effects of ultraviolet radiation on Antarctic marine phytoplankton photosynthesis with particular attention to the influence of mixing. In: Weller CS, Penhale PA (eds) Ultraviolet radıtion and biological research in Antarctica. American Geophysical Unıon, Washington, DC, p 207-227

Hirata Y, Uemura D, Ueda K, Takano S (1979) Several compounds from Palythoa tuberculosa (Coelenterata). Pure appl Chem 51:1875-1883

Holm-Hansen O, Helbling EW, Lubin D (1993) Ultraviolet radiation in Antarctica: inhibition of primary production. Photochem Photobiol 58:567-570

Jerlov NG (1950) Ultra-violet radiation in the sea. Nature 116 : $111-112$

Jokiel PL, York RH Jr (1982) Solar ultraviolet photobiology of the reef coral Pocillopora damicomis and symbiotic zooxanthellae. Bull mar Sci 32:301-315

Jokiel PL, York RH Jr (1984) Importance of ultraviolet radiation in photoinhibition of microalgal growth. Limnol Oceanogr 29:192-199

Jones LW, Kok B (1966) Photoinhibition of chloroplast reactions. I. Kinetics and action spectra. Plant Physiol 41. $1037-1.043$

Karentz D, Cleaver. JE, Mitchell DL (1991a) Cell. survival characteristics and molecular responses of Antarctic phytoplankton to ultraviolet-B radiation. J Phycol 27:326-341

Karentz D, McEuen FS, Land KM, Dunlap WC (1991b) Survey of mycosporine-like amino acid compounds in Antarctic marine organisms: potential protection from ultraviolet exposure. Mar Biol 108:157-166

Kobzik L, Godleski JJ, Brain JD (1990) Oxidative metabolism in the alveolar macrophage: analysis by flow cytometry. J Leukocyte Biol 47:295-303

Lesser MP, Cullen JJ, Neale PJ (1994) Photoinhibition of photosynthesis in the marine diaton Thalassiosira pseudonana during acute exposure to ultraviolet $\mathrm{B}$ radiation: relative importance of damage and repair. J Phycol 30:183-192

Lesser MP, Shick JM (1989) Effects of irradiance and ultraviolet radiation on photoadaptation in the zooxanthellae of Aiptasia pallida: primary production, photoinhibition, and enzymic defenses against oxygen toxicity. Mar Biol 102: $243-255$

Lewis MR, Smith JC (1983) A small volume, short-incubationtime method for measurement of photosynthesis as a function of incident irradiance. Mar Ecol Prog Ser 13: 99-102

Lorenzen CJ (1979) Ultraviolet radiation and phytoplankton photosynthesis. Limnol Oceanogr 24:1117-1120

Nakamura H. Kobayashi J. Hirata Y (1981) Isolation and structure of a $330 \mathrm{~nm}$ UV-absorbing substance. Asterina330 from the starfish Asterina pectinifera. Chem Lett 28: $141.3-1414$

Neale PJ, Lesser MP, Cullen JJ (1994) Effects of ultraviolet radiation on the photosynthesis of phytoplankton in the vicinity of McMurdo Station, Antarctica. In: Weiler CS, Penhale $P$ (eds) Ultraviolet radiation and biological research in Antarctica. American Geophysical Union, Washington, DC, p 125-142

Neale PJ, Lesser MP, Cullen JJ, Goldstone J (1993) Detecting UV-induced inhibition of photosynthesis in Antarctic phytoplankton. US Antaret J 27:122-124
Platt T, Gallegos CL, Harrison WG (1980) Photoinhibition of photosynthesis in natural assemblages of marine phytoplankton. J mar Res 38:687-701.

Renger G, Völker M, Eckert HJ, Fromme R, Hohm-Veit S Gräber $P$ (1989) On the mechanism of Photosystem II deterioration by UV-B irradiation. Photochem Photobiol 49 97-105

Richardson K, Beardall J, Raven RA (1983) Adaptation of unicellular algae to irradiance: an analysis of strategies. New Phytol 93:157-191

Richter M, Rühle W. Wild A (1990) Studies on the mechanism of photosystem II photoinhibition I. The involvement of toxic oxygen species. Photosynth Res 24:237-243

Rodriguez JM, Ko MKW, Sze ND (1991) Role of heterogeneous conversion of $\mathrm{N}_{2} \mathrm{O}_{5}$ on sulphate aerosols in global ozone losses. Nature 352:134-137

Rundel RD (1983) Action spectra and estimation of biolog1cally effective UV radiation. Physiol Plant 58:360-366

Scelfo GM (1984) Relationship between solar radiation and pigmentation of the coral Montipora verrucosa and its zooxanthellae. In: Jokiel PL, Richmond RH, Rogers RA (eds) Coral reef population biology. Hawaii Inst mar Biol tech Rep 37:440-451

Setlow RB (1974) The wavelengths in sunlight effective in producing skin cancer: a theoretical analysis. Proc natl Acad Sci USA 71:3363-3366

Shibata K (1969) Pigments and a UV-absorbing substance in corals and a blue-green alga living in the Great Barrier Reef. Plant Cell Physiol 10:325-335

Shick JM, Dunlap WC, Chalker BE, Banaszak AT, Rosenzweig TK (1992) Survey of ultraviolet radiation-absorbing mycosporine-like amıno acids in organs of coral reef holothuroids. Mar Ecol Prog Ser 90:139-148

Shick JM, Lesser MP, Stochaj WR (1991) Ultraviolet radiation and photooxidative stress in zooxanthellate Anthozoa: the sea anemone Phyllodiscus semoni and the octocoral Clavularia sp. Symbiosis 10:145-173

Sivalingam PM, Ikawa T, Yokohama Y, Nisizawa K (1974) Distribution of a $334 \mathrm{UV}$-absorbing-substance in algae. with special regard of its possible physiological roles. Botanica mar 17:23-29

Smith RC (1989) Ozone, middle ultraviolet radiation and the aquatic environment. Photochem Photobiol 50:459-468

Smith RC, Baker KS (1979) Penetration of UV-B and biologically effective dose-rates in natural waters. Photochem Photobiol 29:311-323

Smith RC, Baker KS (1982) Assessment of the influence of enhanced UV-B on marine primary productıvity. In: Calkins $\mathrm{J}$ (ed) The role of solar ultraviolet radiation in marine ecosystems. Plenum Press, New York, p 509-537

Smith RC, Baker KS (1989) Stratospheric ozone, middle ultraviolet radiation and phytoplankton productivity. Oceanography $2: 4-10$

Smith RC, Baker KS, Holm-Hansen O, Olson RS (1980) Photoinhibition of photosynthesis in natural waters. Photochem Photobiol 31:585-592

Smith RC, Prézelín BB, Baker KS, Bidigare RR, Boucher NP, Coley T, Karentz D, MacIntyre S, Matlick HA, Menzies D, Ondrusek M, Wan Z, Waters KJ (1992) Ozone depletion: ultraviolet radiation and phytoplankton biology in Antarctic waters. Science 255:952-959

Solomon S (1988) The mystery of the Antarctic ozone hole. Rev Geophys 26:131-148

Stolarski R, Bojkov R, Bishop L, Zerefos C, Staehelin J, Zawadony J (1992) Measured trends in stratospheric ozone. Science 256:342-349 
Strid A, Chow WS, Anderson JM (1990) Effects of supplementary ultraviolet-B radiation on photosynthesis in Pisum sativum. Biochem Biophys Acta 1020:260-268

Takano S, Uemura D, Hirata Y (1978) Isolation and structure of a new amino acid, palythine, from the zoanthid Palythoa tuberculosa. Tetrahedron Lett 26:2299-2300

Valenzeno DP, Pooler JP (1987) Photodynamic action. BioSci $37: 270-276$

Vernet M, Brody EA, Holm-Hansen O, Mitchell BG (1994) The response of Antarctic phytoplankton to ultraviolet radiation: absorption, photosynthesis, and taxonomic composition. In: Weiler CS, Penhale PA (eds) Ultraviolet radiation and biological research in Antarctica. American Geophysical Union, Washington, DC, p 143-158

Vernet M, Neori A, Haxo FT (1989) Spectral properties and photosynthetic action in red-tide populations of Prorocen-

This article was submitted to the editor trum micans and Gonyaulax polyedra. Mar Biol 103: 365-371

Vincent WF (1980) Mechanisms of rapid photosynthetic adaptation in natural phytoplankton communies. II. Changes in photochemical capacity as measured by DCMU-induced chlorophyll fluorescence. J Phycol 20:201-211

Vincent $W F$, Roy $S$ (1993) Solar ultraviolet-B radiation and aquatic primary production: damage, protection, and recovery. Environ Rev $1: 1-12$

Vu CV, Allen LH Jr, Garrard LA (1984) Effects of enhanced UV-B radiation (280-320 $\mathrm{nm}$ ) on ribulose-1,5-bisphosphate carboxylase in pea and soybean. Environ Exp Bot 24:131-143

Wood WF (1989) Photoadaptive responses of the tropical red alga Eucheuma striatum Schmitz (Gigartinales) to ultraviolet radiation. Aquat Bot 33:41-51

Manuscript first received: June 23, 1995

Revised version accepted: August 1, 1995 


\section{Erratum}

\section{Re: MP Lesser}

Mar Ecol Prog Ser 132: $287-297$ (1996)

- The confidence intervals for the action spectra in Fig. 3 are incorrect: the action spectra are not statistically different from one another This error does not affect the interpretation of the experimental work provided in the paper that supports the hypothesis that UV absorbing compounds provide incomplete protection in this species of phytoplankton. The author regrets the error, which is his alone. 